\title{
IMPACTOS SOCIOAMBIENTAIS DO “RIO DO PEIXE” NO MUNICIPIO DE CORONEL JOÃO SÁ - BA SOB O OLHAR DO DISCENTE
}

\author{
Social and environmental impacts of "Peixeriver" in Coronel João Sá - Bahia under \\ the students perspective
}

Impactos socioambientales del Río del Pez en la ciudad de Coronel João Sá (BA) desde la perspectiva del alumno

\author{
Luciano Andrade da Silva \\ Márcia Eliane Silva Carvalho ** \\ *Mestre em ciências ambientais UFS -Luciano.bass@hotmail.com \\ ** Professora Pós Doutora DGE/PROFCIAMB/PPGEO/UFS-marciacarvalho_ufs@yahoo.com.br
}

Recebido em 19/10/2019. Aceito para publicação em 20/10/2019. Versão online publicada em 10/11/2019 (http://seer.ufrgs.br/paraonde)

\section{Resumo:}

O presente trabalho teve como objetivo analisar os impactos socioambientais do rio do Peixe na cidade de Coronel João Sá-BA sob o olhar do discente do Colégio Estadual Santo Antônio. Analisar os impactos a partir do olhar do aluno é por entender que este é sujeito do conhecimento e que a pesquisa deve partir de sua realidade. Para tal, a aula de campo é fundamental, pois, é no campo que os discentes identificam in lócus causas e consequências do impacto ambiental, bem como entendem a importância da água para vidado homem relacionado a realidade local. Assim, a proposta metodológica foi dividida em três etapas. A primeira, em sala, alunos juntos com o professor de geografia destacaram várias problemáticas que ocorrem na cidade de Coronel João Sá-BA. Após discussões foi definido estudar o rio do Peixe, visto que este apresenta elementos a serem observados como poluição, descarte de resíduos sólidos e desmatamento. No segundo momento foi realizada atividade de campo com uso de celulares para documentar a realidade em análise, como também foi utilizado um drone. Como pós-campo, no terceiro momento, foi realizada a culminância de atividades, onde os discentes expressaram sob seu olhar os impactos socioambientais do rio do Peixe através de produção didática como: vídeo, dança, música autoral, fantoche, pintura, poema, maquete. Sendo assim, o caminho para conseguir qualidade de vida em equilíbrio com ambiente requer práticas pautadas na ética ambiental e na realidade vivida, daí a importância dos estudos de campo.

Palavras-chave: rio do Peixe, impactos socioambientais, aula de campo.

\footnotetext{
Abstract:

The present study aimed to analyze the social and environmental impacts of Peixe River in the municipality of Coronel João Sá - Bahia under the look of the students of Santo Antônio State School. Analyzing the impacts from the student perspective is to understand that the student is the subject of knowledge and that the research must start from its reality. For this, the field class is fundamental, because it is in the field that students identify in locus causes and consequences of environmental impact, as well as understand the importance of water for human life related to local reality. Thus, the methodological proposal was divided into three stages. First, in class, students together with the geography teacher highlighted several problems that occur in the municipality of Colonel JoãoSá Bahia. After discussions it was defined to study the Peixe River, as it presents elements to be observed such as pollution, solid waste disposal and deforestation. In the second moment, field activity was carried out using cell phones to document the reality under analysis, as well as a drone. As a post-field, in the third moment, the culmination of activities was fulfilled, where students
} 
expressed under their perspective the social and environmental impacts of the Peixe River through didactic production such as video, dance, authorial music, puppet, painting, poem and model. Thus, the way to achieve life quality in balance with the environment requires practices based on environmental ethics and lived reality, hence the importance of field studies.

Key-words: Peixe River, social and environmental impacts, field class.

\section{Resumen:}

Se objetivó analizar en este estudio los impactos socioambientales del Río del Pez en la ciudad de Coronel João Sá (BA) desde la perspectiva de los alumnos del Colegio Estadual de Santo Antonio. Analizar los impactos desde la perspectiva del alumno es comprender que este es el sujeto del conocimiento y que se debe empezar la investigación desde su realidad. Para esto, la clase de campo es fundamental porque es en el campo que los estudiantes identifican in loco las causas y las consecuencias del impacto ambiental, así como entienden la importancia del agua para la vida humana relacionada con la realidad local. Así, se dividió la propuesta metodológica en tres etapas. En la primera etapa, en clase, los alumnos junto con el profesor de geografía destacaron varios problemas que ocurren en la ciudad de Coronel João Sá (BA). Después de las discusiones, se definió estudiar el Río del Pez, ya que este río presenta elementos a observar, como la contaminación, la eliminación de residuos sólidos y la deforestación. En el segundo momento, la actividad de campo se llevó a cabo utilizando teléfonos celulares para documentar la realidad bajo análisis, así como también se utilizó un dron para obtener las imágenes del área. Después de la clase de campo, en el tercer momento, se llevó a cabo la culminación de las actividades, donde los alumnos expresaron desde su perspectiva los impactos socioambientales del Río del Pez a través de la producción didáctica de videos, danzas, músicas propias de los alumnos, títeres, pinturas, poemas y maquetas. Por lo tanto, el camino para lograr una calidad de vida en equilibrio con el medio ambiente requiere prácticas basadas en la ética ambiental y la realidad vivida, lo que justifica la importancia de los estudios de campo.

Palabras clave: Río del Pez, impactos socioambientales, clase de campo.

\section{Introdução}

A cidade de Coronel João Sá-BA está situada na mesorregião do nordeste da

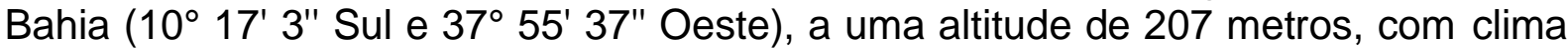
semiárido e grandes períodos de estiagem. A população é de aproximadamente 17.066 habitantes (IBGE, 2010), dos quais 59\% na zona rural e $41 \%$ na zona urbana.

Diante dos grandes períodos de seca, a escassez de água é um dos problemas para a população. Por outro lado, a cidade se defronta também com grandes problemas de ordem socioambiental, como destinação incorreta dos resíduos sólidos, crescimento desordenado da cidade, desemprego, pobreza, poluição hídrica, entre outros.

Diante desta problemática, a escola possui um papel fundamental para a formação de uma consciência ambiental para além das dimensões biológicas, químicas e físicas. Para tal é preciso que a educação possa direcionar suas práticas pedagógicas para a sustentabilidade ambiental e para ações voltadas para a fiscalização e atuação cidadã frente aos interesses locais.

Segundo Penteado (2010, pag. 61) "É preciso dar um passo transformador. Esse passo aponta na direção de se orientar os trabalhos escolares por uma lógica ambiental, a fim de que passemos da escola informativa para a escola formadora" isto é, transgredir com a educação tradicional, tecnicista, burocrática, na qual o aluno é visto como mero receptáculo de informação.

ParaOnde!?, Porto Alegre, v.12 n.2, p.135-145, 2019.http://seer.ufrgs.br/paraonde Edição Especial - III Colóquio de Pesquisadores em Geografia Física Ensino de Geografia 
Dessa maneira, aproximar a escola com seu entorno, é por entender que a escola possui papel importante na sensibilização dos alunos e da comunidade diante dos impactos socioambientais, haja vista que o âmbito escolar presta papel social significante na formação do cidadão crítico, participativo e consciente diante dos problemas ambientais.

Diante deste contexto, o trabalho tem como objetivo analisar os impactos socioambientais do rio do Peixe na cidade de Coronel João Sá-BA sob o olhar do discente do Colégio Estadual Santo Antônio, como também instigar a percepção do discente em relação às causas e conseqüências da poluição do rio do Peixe, possibilitando construir ações voltadas para alterar a realidade local.

O rio do Peixe tem sua nascente na cidade de Pedro Alexandre -BA e antes de desaguar no Vaza Barris adentra na cidade de Coronel João Sá- BA , assim como outros rios urbanos brasileiros, sofre com lançamento de efluentes domésticos, resíduos sólidos, desmatamento da vegetação ciliar devido ocupação desordenada.

Dessa maneira, diante das problemáticas elencadas o trabalho de campo serve como estratégia para enfrentar a fragmentação do conhecimento, romper com a monotonia em sala de aula, bem como estabelecer a relação local/global, de acordo com Compiani, (2007, p.32) "Por meio das atividades de campo, a categoria geocientífica "lugar" é entendida como o locus de ligação com o todo, uma interação sutil da particularidade e da generalização".

Destarte, a escola engajada com a localidade que está inserida deve oportunizar a realização de atividades pedagógicas que coloque os discentes diante de sua realidade e que este entenda o mundo a partir de seu local de vivencia, de acordo com Cavalcanti (2010, p.6) trabalhar os fenômenos a partir do lugar do sujeito, de sua realidade permite maior identificação dos alunos com o conteúdo, atribuindo maior sentido ao que é estudado, permitindo que façam relações entre a realidade e os conteúdos escolares. Desse modo, atividade de campo potencializa a unidade teoria-prática tornando significativo o processo ensino-aprendizagem segundo Lopes e Pontuschka (2009, p. 174):

O Estudo do Meio pode ser compreendido como um método de ensino interdisciplinar que visa proporcionar para alunos e professores contato direto com uma determinada realidade, um meio qualquer, rural ou urbano, que se decida estudar. Esta atividade pedagógica se concretiza pela imersão orientada na complexidade de um determinado espaço geográfico, do estabelecimento de um diálogo inteligente com o mundo, com o intuito de verificar e de produzir novos conhecimentos.

O trabalho de campo permite aos discentes se defrontar com sua realidade, de modo que possam questionar e desenvolver o olhar crítico investigativo, por outro lado organizar as informações extraídas para a construção de conhecimento que pode se dar na elaboração de materiais didáticos como: vídeo documentário, maquete, música, pintura, poema, fantoche, materiais que possibilitamexpressar o que foi apreendido na aula de campo colocando os alunos como protagonistas e autores de seu próprio conhecimento.

Dessa maneira, se faz necessário a ampliação do direito a informação e da

ParaOnde!?, Porto Alegre, v.12 n.2, p.135-145, 2019.http://seer.ufrgs.br/paraonde Edição Especial - III Colóquio de Pesquisadores em Geografia Física Ensino de Geografia 
educação ambiental na busca de uma ética ambiental que proporcione aos discentes e comunidade escolar uma mudança no modo de pensar o mundo, viver a vida, isto é, mudança de valores e atitudes que possam direcionar a vida na construção da sustentabilidade.

\section{Metodologia}

Esta proposta envolveu alunos do $1^{\circ}$ ano $A, B$ e $C$ matutino e $2^{\circ}$ ano $A, B$ e $3^{\circ}$ A vespertino do ensino médio do Colégio Estadual Santo Antonio da cidade de Coronel João Sá-BA totalizando aproximadamente 160 discentes com faixa etária de 13 a 16 anos.

A proposta metodológica foi dividida em três etapas que fundamentaram a pesquisa. A primeira, em sala, os alunos juntos com o professor de geografia fizeram um debate e destacaram várias problemáticas que ocorre na cidade de Coronel João Sá-BA. A partir das problemáticas foi realizada uma discussão e reflexão entre os discentes mediados pelo professor de geografia e assim, chegaram ao consenso e definiram estudar o rio do Peixe, visto que, este apresenta elementos a ser observado como poluição, descarte de resíduos sólidos e desmatamento.

O segundo momento foi realizado a aula de campo com os discentes, professores de biologia e geografia, devido a grande quantidade de alunos foi dividido no turno matutino os discentes do $1^{\circ}$ ano $A, B$ e $\mathrm{C}$ e no turno vespertino $2^{\circ}$ ano $A, B$ e $3^{\circ}$ ano $A$ para que estes pudessem analisar os impactos socioambientais do rio do Peixe, de acordo com Compiani, (2007,p.35):

O campo é o lugar onde o conflito entre o mundo (o exterior) e as idéias (o interior) ocorre em toda sua intensidade: por isto é possível iniciar a construção de conhecimentos a partir dele, buscando informações e formulando conceitos porque lá está o/a lugar/natureza para ser observado/a e interpretado/a.

O trabalho de campo é fundamental para uma analise integrada dos problemas locais, visto que, proporciona uma melhor compreensão da conjuntura social e histórica do ambiente que cerca os alunos, fazendo com que a compreensão do discente sobre determinado fenômeno seja contextualizado.

Para realização da atividade de campo os discentes utilizaram bloco de anotações, caneta, gravador, celular, máquina fotográfica, drone para fazer filmagem aérea do rio do Peixe.

A aula de campo proporcionou buscar informações com um olhar que vá além do que a paisagem mostra. $O$ terceiro momento ocorreu a culminância de atividades realizada no dia 11 de junho, onde os discentes puderam expressar sob seu olhar os impactos socioambientais do rio do Peixe através de produção didática como: vídeo, dança, música autoral, fantoche, pintura, poema, maquete.

A escola que busca romper com a educação tradicional deve mudar em seu projeto o trabalho escolar, que de informativo passa ser essencialmente formativo, levando para o aluno uma melhor compreensão do mundo que o cerca, onde este irá aprender a organizar o seu comportamento social para resolver questões.

ParaOnde!?, Porto Alegre, v.12 n.2, p.135-145, 2019.http://seer.ufrgs.br/paraonde Edição Especial - III Colóquio de Pesquisadores em Geografia Física Ensino de Geografia 


\section{Desenvolvimento}

$\mathrm{Na}$ atividade de campo realizada no dia 09 de maio no turno matutino com os discentes do $1^{\circ}$ ano $\mathrm{A}, \mathrm{B}$ e $\mathrm{C}$ e vespertino $2^{\circ}$ ano $\mathrm{A}, \mathrm{B}$ e $3^{\circ} \mathrm{A}$, com acompanhamento dos professores de geografia e biologia, os alunos puderam se deparar com os problemas ambientais locais de modo a questionar e buscar respostas (Figura 1).

Figura 1 - Discentes observando os impactos do rio do Peixe

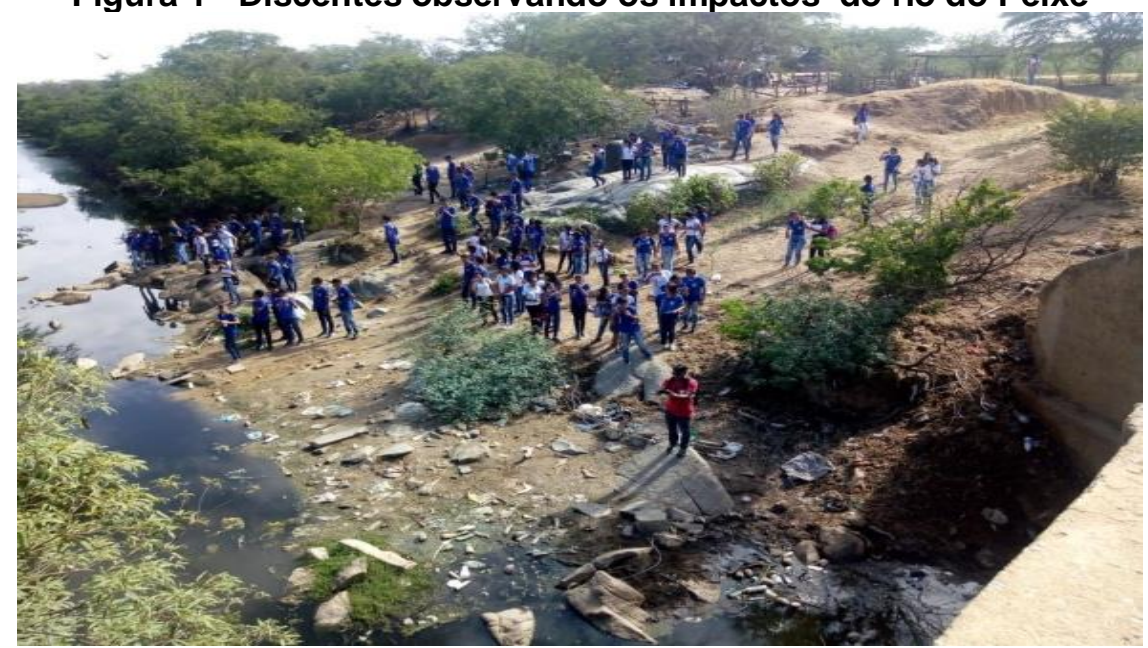

Fonte:SILVA, L. A. 2018.

Um dos pontos críticos do rio do Peixe conhecido como "chiqueiro dos porcos" foi perceptível o descarte inadequado de resíduos sólidos na margem e leito do rio, sendo que os porcos utilizam da água contaminada para dessedentação. Os discentes destacaram que esses animais são abatidos e a carne comercializada na feira da cidade, diante de tal fato, foi discutido com os alunos quais medidas poderiam ser tomadas, estes colocaram que a realocação do "chiqueiro dos porcos" para outro local pode ser uma ação mitigadora. (Figuras 2 e 3).

\section{Figura 2 - Resíduos sólidos na margem}

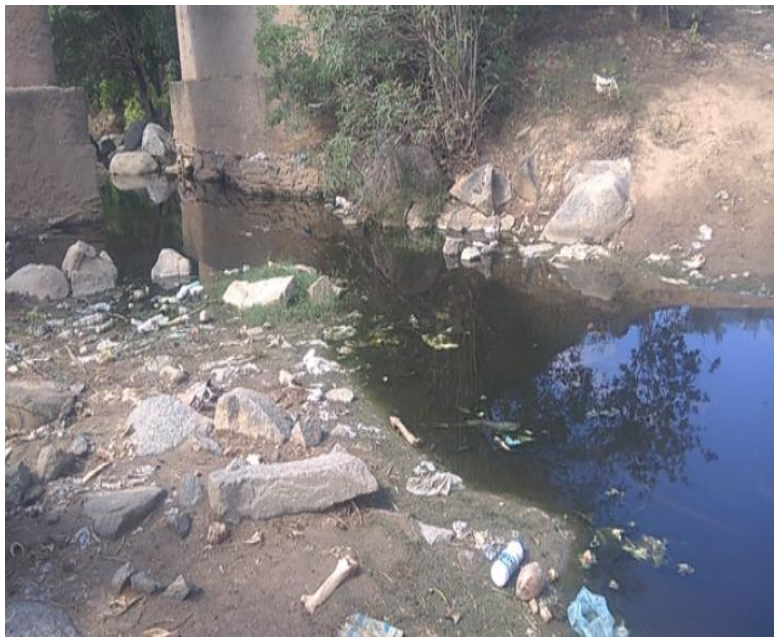

Figura 3 - Dessedentação de animal e leito do rio do Peixe

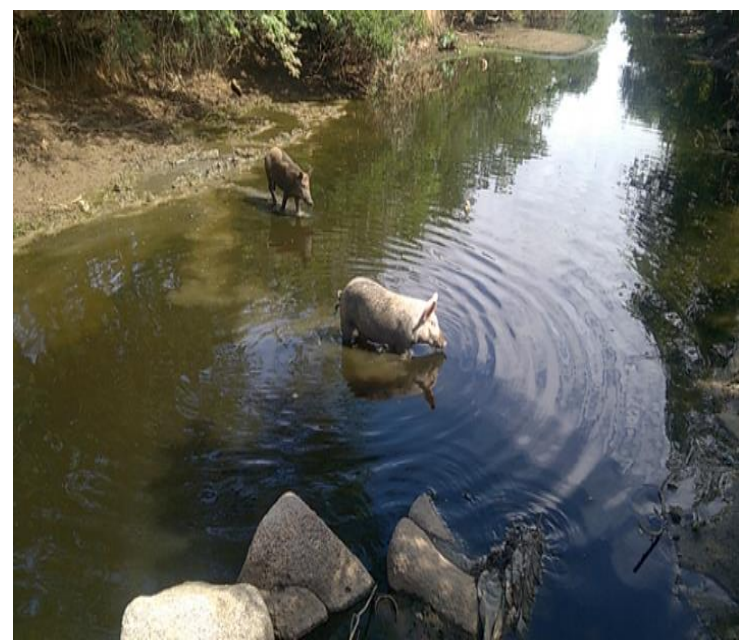

Fonte:SILVA, L. A. 2018.

ParaOnde!?, Porto Alegre, v.12 n.2, p.135-145, 2019.http://seer.ufrgs.br/paraonde Edição Especial - III Colóquio de Pesquisadores em Geografia Física Ensino de Geografia 
Os resíduos sólidos encontrados no curso de água e nas margens demonstram que a população não apenas assiste o dano ambiental passivamente, como ainda contribui para aumentar a degradação. A disposição de lixo em locais inadequado traz impactos negativos ao ambiente, muitas pessoas não refletem sobre as consequências danosas que causam ao ambiente local. De acordo com Mucelin e Belline (2008, p. 113):

Essas práticas habituais podem provocar, entre outras coisas, contaminação de corpos d'água, assoreamento, enchentes, proliferação de vetores transmissores de doenças, tais como cães, gatos, ratos, baratas, moscas, vermes, entre outros. Some-se a isso a poluição visual, mau cheiro e contaminação do ambiente.

Dessa maneira, outros problemas foram identificados na aula de campo pelos discentes, o contato com as problemáticas locais os fizeram questionar quais as conseqüências para os problemas visualizados como assoreamento, desmatamento da mata ciliar, além dos efluentes domésticos direcionados para o rio do Peixe, sem nenhum tipo de tratamento trazendo problemas paisagísticos de saúde e ambientais. Os discentes em campo puderam observar e interpreta sua realidade de modo a construir indagações de como pode ser minimizada a problemática em questão.

Para investigar algumas conseqüências dos impactos ambientais dos despejos de efluentes domésticos, os discentes do $3^{\circ}$ ano vespertino entrevistaram a técnica de enfermagem que trabalha no posto de saúde da cidade de Coronel João Sá-BA, segundo esta, a poluição do rio do Peixe é um fator agravante que ocasiona várias doenças como; verminose, dengue, diarreia, amebíase, entre outras, são mais comuns nas pessoas que moram próximo ao rio e utilizam a água contaminada.

Outro processo decorrente dos efluentes líquido é a eutrofização excesso de nutriente fósforo ou nitrogênio que causa a mortandade de peixes. Segundo Parfitt, (2002, p.99) "No Brasil, $70 \%$ dos rios do território brasileiro estão contaminados, pois $80 \%$ dos esqotos domiciliares não recebem tratamento" (Figuras 4 e 5).

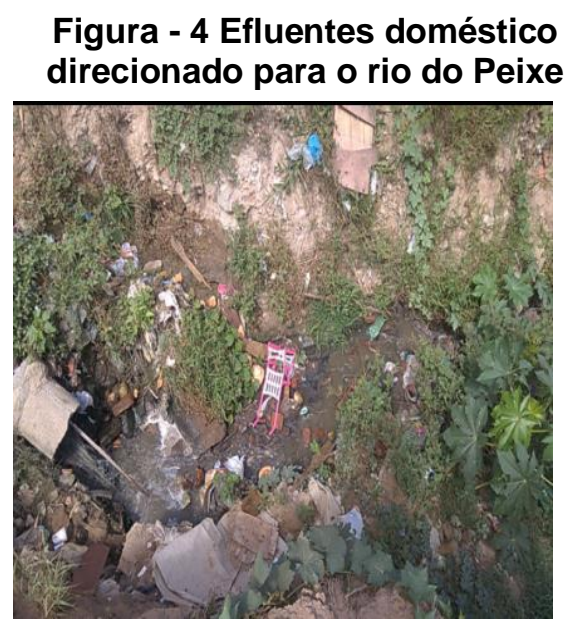

Figura 5- Professor de Biologia explicando o processo de eutrofização

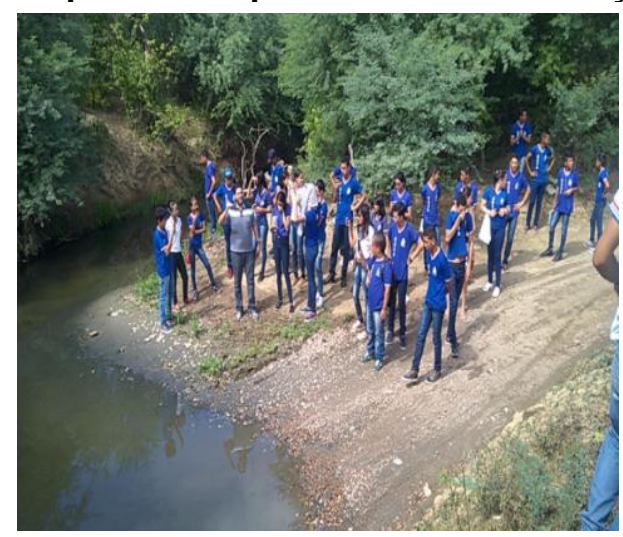

Fonte:SILVA, L. A. 2018.

Outro fato que chamou atenção dos discentes foi o desmatamento da mata ciliar sendo a ocupação humana uma das responsáveis por esse fator, contudo, no

ParaOnde!?, Porto Alegre, v.12 n.2, p.135-145, 2019.http://seer.ufrgs.br/paraonde Edição Especial - III Colóquio de Pesquisadores em Geografia Física Ensino de Geografia 
dia 09 de maio quando ocorreu a aula de campo em um trecho do rio chamado ponte do Sanharol a mata Ciliar estava presente, sendo que, quase um mês depois no dia 11 de junho houve a retirada da mata ciliar desse trecho do rio do Peixe, o acontecimento foi observado por discentes que passam diariamente pela ponte, e estes buscaram respostas pelo qual ocorreu o desmatamento e a justificativa encontrada segundo moradores que foi para diminuir pernilongos, muriçocas, que no período de estiagem encontra-se em grande quantidade. Contudo, fica evidente a falta de conhecimento da gestão pública da importância da mata ciliar para proteção dos cursos d'água. (Figuras 6 e 7).

Figura 6- rio do peixe com Mata Ciliar

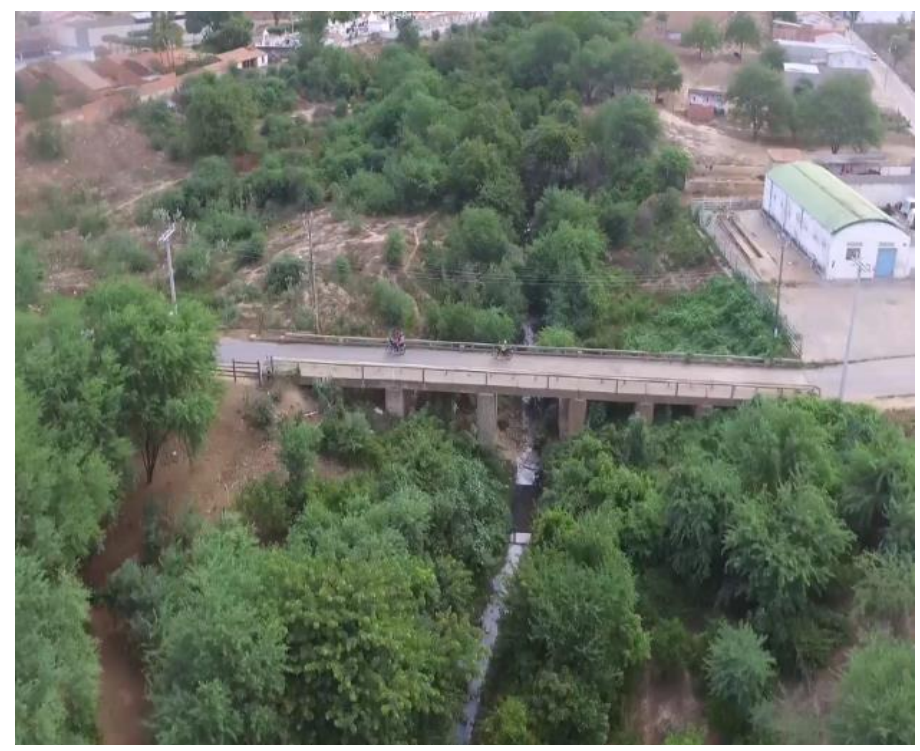

Fonte:SILVA, L. A. 2018.

Figura 7- desmatamento da mata Ciliar

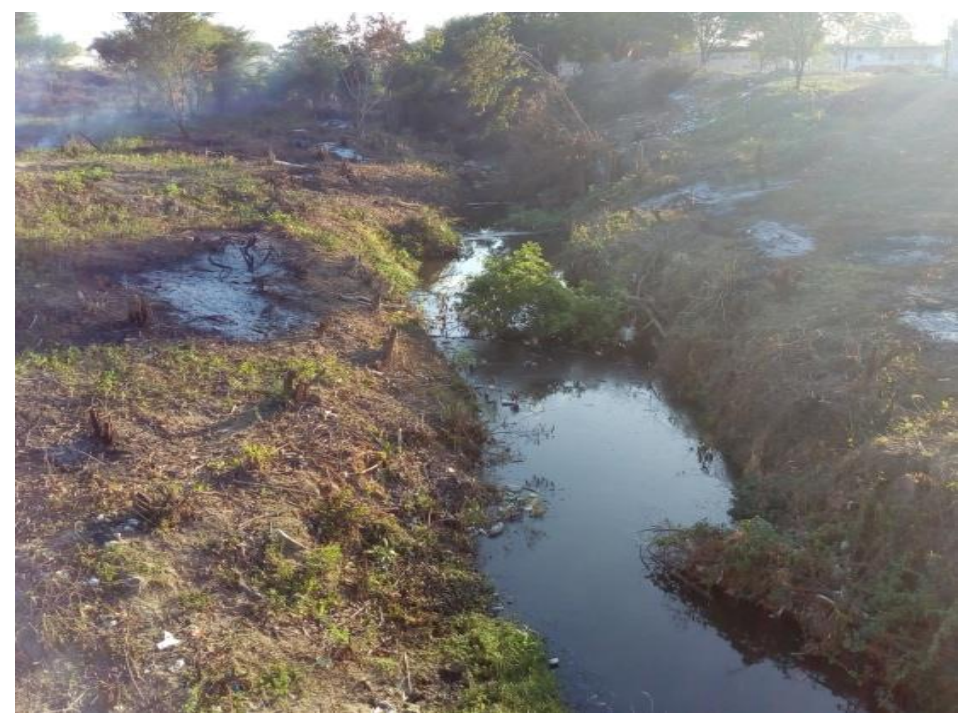

Fonte:SILVA, L. A. 2018.

ParaOnde!?, Porto Alegre, v.12 n.2, p.135-145, 2019.http://seer.ufrgs.br/paraonde Edição Especial - III Colóquio de Pesquisadores em Geografia Física Ensino de Geografia 
Considerando o objetivo de analisar os impactos socioambientais do rio do Peixe e a percepção dos discentes sobre as causas e consequências da poluição, os discentes perceberam o valor que a água tem como meio de subsistência e sustentabilidade para a vida do homem associado à realidadelocal.

Desse modo, os alunos com a orientação do professor em sala de aula, dialogaram em busca da construção de conhecimento através de produções didáticas como: maquetes, vídeos, teatro de fantoche, músicas, dança e pintura. Os discentes escolheram as atividades de acordo com o que mais se identificavam (Figura 8).

\section{Figura 8 - discentes preparando as produções didáticas}

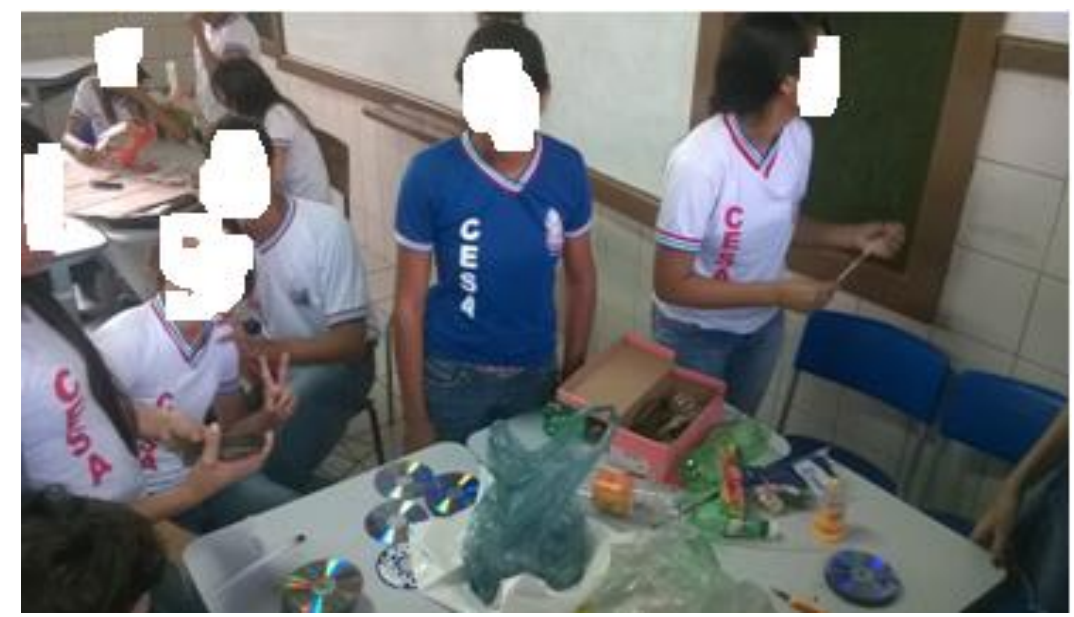

Fonte:SILVA, L. A. 2018

Dessa maneira, no dia 11 de junho 2018 foram apresentadas as atividades didáticas no Colégio Estadual Santo Antônio nos turnos matutino, vespertino e noturno onde os discentes puderam expressar as contradições do espaço geográfico através de maquetes, vídeos, teatro de fantoche, músicas, dança e pintura de acordo, com a visão e leitura que os alunos identificaram na aula de campo das causas e conseqüências dos impactos socioambientais no rio do Peixe (FIGURAS 9 e 10).

Figuras - 9 e 10 Representação do impactos socioambientais do rio do Peixe por maquetes
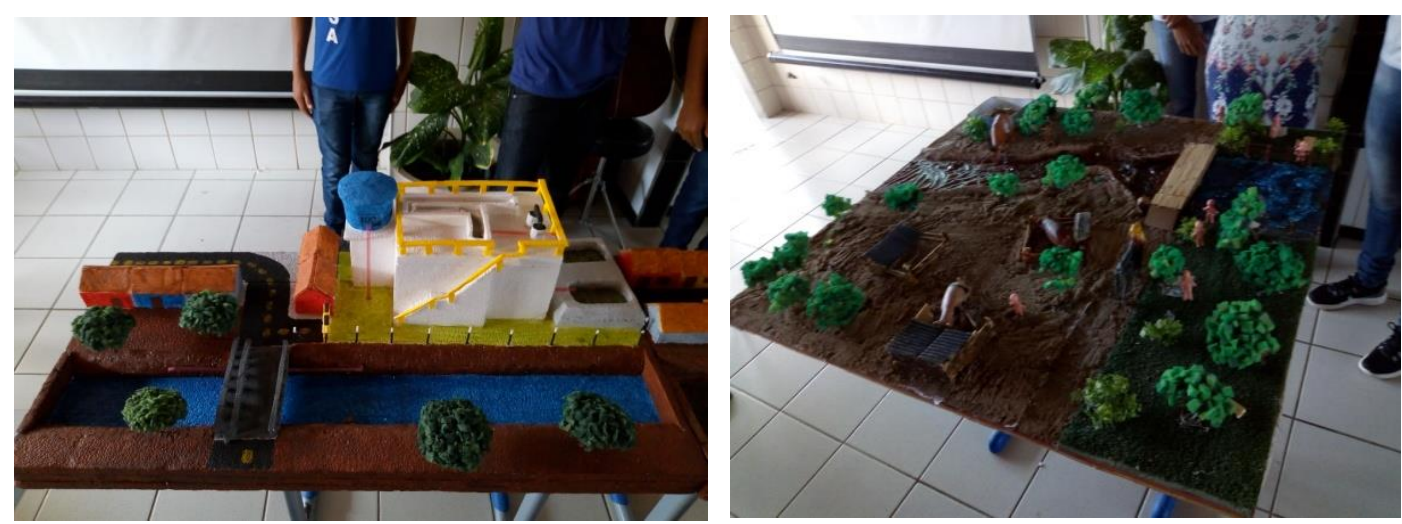

Fonte:SILVA, L. A. 2018.

ParaOnde!?, Porto Alegre, v.12 n.2, p.135-145, 2019.http://seer.ufrgs.br/paraonde Edição Especial - III Colóquio de Pesquisadores em Geografia Física Ensino de Geografia 
Uso de maquete é uma ferramenta pedagógica que auxilia na exposição do assunto como também amplia as oportunidades de compreensão do espaço geográfico e da realidade em que os alunos se situam. Outra forma de exposição foi através de pinturas, vídeos, músicas, teatro de fantoche (Figuras 11e 12)

Figura 11 - Teatro de fantoches

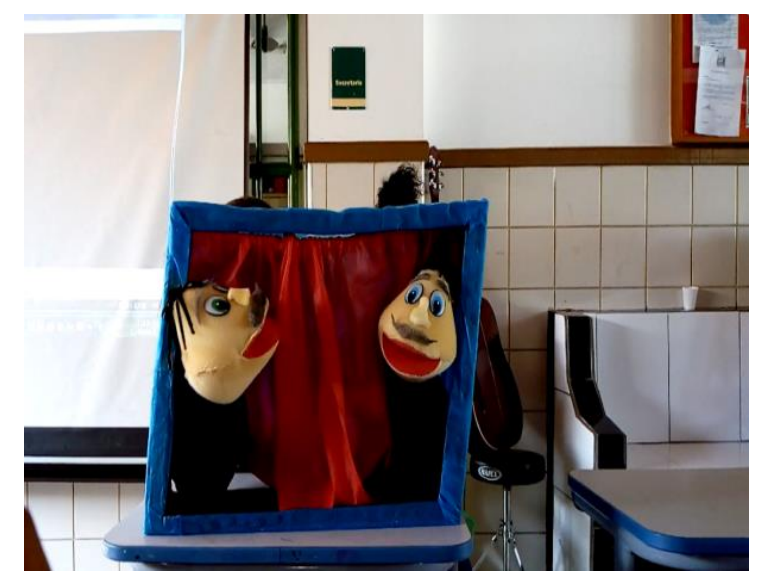

Figura 12 - Vídeo documentário

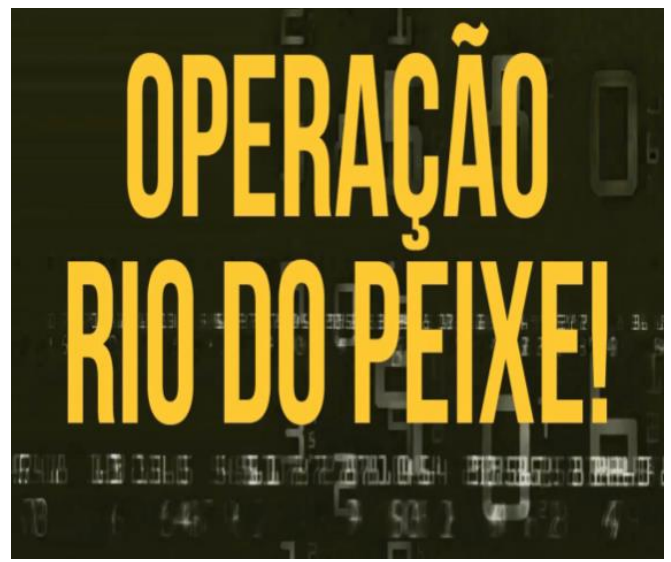

Fonte:SILVA, L. A. 2018.

As ferramentas pedagógicas utilizadas fazem parte do cotidiano dos jovens e pode ser utilizadas no ensino-aprendizagem, de maneira a tornar mais interessante aos olhos dos estudantes, possibilitando problematizar o conhecimento num processo de dialogo de saberes.

Sendo assim, os discentes retrataram de forma lúdica, critica e criativa, os impactos socioambientais do rio do Peixe, um exemplo da criatividade foi a utilização de drone para produção de vídeo documentário e fotos despertando outros olhares para problemática do rio de forma dinâmica, interativa e prazerosa.

\section{Considerações finais}

A atividade teve como propósito descortinar a realidade e ir à essência dos fatos, analisar os impactos socioambientais do rio do Peixe não se restringindo apenas a mostrar a falta de planejamento da cidade e de políticas públicas, mas também fornecer para os discentes um instrumental teórico para que estes possam tomar conhecimento não apenas da problemática do saneamento básico e da falta de medidas públicas, como também tomar consciência de que são sujeitos históricos capazes de interferir na sua realidade.

Foi perceptível a ausência de políticas públicas que possam minimizar os impactos socioambientais, outro fator que chama atenção é que muitas pessoas são co-responsáveis pela degradação do rio do Peixe. Assim sendo, a escola pode e deve promover um trabalho de sensibilização para os discentes estendendo para a sociedade. Dessa forma, ultrapassar os muros da escola faz parte das ações pedagógicas para uma educação escolar voltada á formação de sujeitos críticos e transformadores, de modo que os discentes percebam que são capazes através do conhecimento transformar ou propor mudanças da sua realidade local.

Posto isto, como desdobramento e dando continuidade a atividade

ParaOnde!?, Porto Alegre, v.12 n.2, p.135-145, 2019.http://seer.ufrgs.br/paraonde Edição Especial - III Colóquio de Pesquisadores em Geografia Física Ensino de Geografia 
pedagógica desenvolvida pelos discentes será elaborada uma carta manifesto produzida pelos discentes no qual, junto com um vídeo documentário sobre os impactos socioambientais no rio do Peixe, será entregue na Câmara de Vereadores da cidade na busca de proporcionar debates e discussões a cerca da problemática em questão e ações que possam minimizar a degradação ambiental local.

A escola é um local adequado para realização de um ensino ativo e participativo que possibilite ações para os discentes exercerem sua cidadania, descortinando a realidade local. Deste modo, a escola comprometida com a formação do sujeito crítico e participativo deve ter como ponto de partida a realidade social do discente. Dessa maneira, aulas de campo quando bem planejada aproxima a escola do seu entorno instrumentalizando os discentes a perceberem que são coparticipantes na busca por intervenção de sua realidade.

\section{Referências}

COMPIANI, Maurício O lugar e as escalas e suas dimensões horizontal e vertical nos trabalhos práticos: implicações para o ensino de ciências e educação ambiental Ciência \& Educação (Bauru), vol. 13, núm. 1, abril, 2007, pp. 29-45

CAVALCANTI, Lana de Souza. A geografia e a realidade escolar contemporânea: avanços, caminhos, alternativas , Anais do I seminário nacional: currículo em movimento - Perspectivas Atuais Belo Horizonte, novembro de 2010

LOPES, Claudivan S.; PONTUSCHKA, Nídia N. Estudo do meio: teoria e prática.Geografia (Londrina) v. 18, n. 2, 2009

http://www.uel.br/revistas/uel/index.php/geografia/

MUCELI, Carlos Alberto, BELLINE, Marta. Lixo e impactos ambientais perceptíveis no ecossistema urbano, Uberlandia, 2008.Disponivel em http://www.scielo.br/pdf/sn/v20n1/a08v20n1.

PENTEADO, Heloísa Dupas, Meio Ambiente e formação de professores. 7 ed. São Paulo: Cortez, 2010.

PARFITT, ClaureMorrone. Impactos urbanos em áreas de interesse e proteção ambiental. Porto Alegre. 2002.. Disponivel em

ParaOnde!?, Porto Alegre, v.12 n.2, p.135-145, 2019.http://seer.ufrgs.br/paraonde Edição Especial - III Colóquio de Pesquisadores em Geografia Física Ensino de Geografia 
https://lume.ufrgs.br/bitstream/handle/10183/4701/000414202.pdf?sequence=1\&isAll owed =y Acessado 15/06/2018. 